\title{
Is the Botryococcus braunii Dry Biomass an Adjuvant for Anti-UVB Topical Formulations?
}

\author{
Maíra Bueno Ariede ${ }^{1}$, Ana Lucia Morocho-Jácome ${ }^{1}$, Thalita Marcílio Candido ${ }^{1}$, \\ Felipe Rebello Lourenço ${ }^{1}$ (D), Edna Tomiko Myiake Kato ${ }^{1}$, Fabiana Vieira Lima ${ }^{1,2}$, \\ Catarina Rosado ${ }^{3}$ (D), Maria Valéria Robles Velasco ${ }^{1}$, João Carlos Monteiro de Carvalho ${ }^{4}$ \\ and André Rolim Baby ${ }^{1, * \mathbb{D}}$ \\ 1 Department of Pharmacy, Faculty of Pharmaceutical Sciences, University of São Paulo, \\ 05508-900 São Paulo, Brazil; mbariede@usp.br (M.B.A.); anamorochoj@usp.br (A.L.M.-J.); \\ thalitamcandido@usp.br (T.M.C.); feliperl@usp.br (F.R.L.); myiake@usp.br (E.T.M.K.); \\ fabianavlimag@gmail.com (F.V.L.); mvrobles@usp.br (M.V.R.V.) \\ 2 Department of Health Sciences, Universidade Federal do Espírito Santo, São Mateus, \\ 29932-540 Espírito Santo, Brazil \\ 3 CBIOS-Universidade Lusófona's Research Center for Biosciences and Health Technologies, \\ 1749-024 Lisbon, Portugal; p1657@ulusofona.pt \\ 4 Biochemical and Pharmaceutical Technology Department, Faculty of Pharmaceutical Sciences, \\ University of São Paulo, 05508-900 São Paulo, Brazil; jcmdcarv@usp.br \\ * Correspondence: andrerb@usp.br; Tel.: +5511-3091-2358
}

Received: 7 April 2020; Accepted: 23 April 2020; Published: 26 April 2020

\begin{abstract}
Several topical products have been developed to avoid the harmful effects from ultraviolet (UV) radiation, such as sunscreens. Research for actives from natural sources is increasing due to the fact that chemical filters could induce adverse events. The microalgae Botryococcus braunii has potential interest in cosmetic applications. Specialized literature reported that B. braunii aqueous extract induced a reduction in skin dehydration and collagen production and promoted antioxidant activity. This research aimed to produce B. braunii biomass and to investigate its contribution regarding photoprotection. Formulations containing B. braunii dry biomass, with or without UV filters into vehicles composed of an emulsifying polymer or a self-emulsifying base, were evaluated in vitro by means of photoprotective activity and photostability. B. braunii dry biomass did not provide adequate photoprotection efficacy; however, it was observed that the self-emulsifying base promoted better sun protection factor (SPF) in comparison with the emulsifying polymer.
\end{abstract}

Keywords: Botryococcus braunii; microalgae; photoprotection; functional ingredient; UV radiation

\section{Introduction}

Ultraviolet (UV) radiation is one of the main environmental factors that induces skin damages [1-3]. UVA rays (320-400 $\mathrm{nm}$ ) penetrate deeply in the skin affecting both epidermis and dermis, since they react with molecular oxygen, generating reactive species that induce DNA damage, skin inflammatory responses and photoaging. UVB radiation $(290-320 \mathrm{~nm})$ only reaches the epidermis, causing direct damage to the DNA, increased oxidative stress, photoimmunosuppression, erythema, melanogenesis, inflammation and even skin cancer [2-5].

In order to cope with exposure to UV radiation, various organisms have developed defense mechanisms to reduce the damages caused by this stressor agent, as the expression and regulation of antioxidant enzymes, molecular repair and synthesis of compounds with photoprotective actions, such as flavonoids in various plants, melanin in animals and humans, mycosporine in fungi, and mycosporine-like amino acids, detected in cyanobacteria, algae and animals $[5,6]$. 
Due to the limited capacity of such protective mechanisms, sunscreen formulations were developed with chemical and/or physical filters that are able to absorb, reflect or spread the incident UV radiation $[7,8]$, minimizing its interaction with the cutaneous tissue. However, adverse reactions have been induced by the topical use of chemical filters, such as the occurrence of photoallergic or phototoxic contact dermatitis, probably due to by-products formation [1,8-11].

This problem has been tackled with strategies that combine UV filters with compounds with antioxidant action, such as polyphenols, that avoid the harmful effects of UV light or even assist in the photostability of the filters $[5,6,8,11,12]$.

In the search for new substances with such photoprotective action, several bioactive compounds from natural sources have been probed, in compliance with the current preference of consumers for ecologically and sustainably produced cosmetics, with lower amounts of synthetic ingredients $[2,7,13,14]$.

Some microalgae have received increasing attention as potential sources of such bioactive compounds since they present a great variety of components that can contribute to the formulation by promoting antioxidant action and protection against UV radiation. For instance, mycosporine-like amino acids from microalgae, macroalgae and cyanobacteria are able to absorb UV radiation $(310-360 \mathrm{~nm})$. Such compounds are included in the groups of carotenoids, fatty acids, polysaccharides, vitamins, peptides and sterols [13-15]. These substances are traditionally extracted from plants; however, microalgae present greater photosynthetic conversion efficiency of the sunlight, ensuring a superior yield, and allow the manipulation and targeting of their biosynthetic pathways for the production and accumulation of components of interest, by making changes in the growing conditions [15,16].

Numerous products containing microalgae have already been marketed, which are intended for skin care, hair care and also for sun protection. Several patents report the action of microalgae-using cells, its components or even extracts-in cosmetics $[9,13,17]$.

Botryococcus braunii, an unicellular photosynthetic microalgae, is considered a biofuel source due to the ability to produce long unsaturated hydrocarbon chains, representing up to $75 \%$ of its dry mass $[13,18,19]$. Regarding the hydrocarbon produced, this microalgae can be classified into three types: (i) type A, which comprises n-alkadienes and mono-, tri-, tetra- and pentanes, which are derived from C23 to C33 fatty acids; (ii) type B, which produces triterpenoid hydrocarbons, known as botriococenes (C30-C37); and (iii) type L, which produces tetraterpenoids (C40) $[19,20]$. However, B. braunii contains carotenoids, which are well known antioxidant compounds and, therefore, capable of eliminating free radicals, preventing oxidative damage to cells and tissues, and also contains phenolic compounds [19].

In vitro studies to probe the cosmetic applicability of $B$. braunii aqueous extracts have shown that it can induce collagen synthesis, stimulate adipocyte differentiation and has anti-inflammatory and antioxidant activities. It has also shown to be able to reduce cutaneous dehydration, thus influencing the appearance, metabolism, mechanical properties and barrier function of the skin [13]. In addition, a cytotoxicity test in NIH3T3 cells, HaCaT keratinocytes and MSC cells showed that the aqueous extract, at concentrations of 0.0025 to $0.1 \%$, did not interfere with the cellular viability [13].

The present study aimed to verify the impact of microalgae in the anti-UVB efficacy of a photoprotective cosmetic formulation containing a sunscreen system composed of avobenzone and octyl $p$-methoxycinnamate. B. braunii was cultivated under controlled conditions and its dry biomass was incorporated in two semisolid vehicles, one containing an emulsifying polymer and the other a self-emulsifying base. The photoprotective capacity and photostability of these formulations were assessed in vitro through the determination of the sun protection factor (SPF) and critical wavelength.

\section{Materials and Methods}

\subsection{Growth and Production of Microalgae}

B. braunii was cultured in CHU medium [21] using properly sterile systems. B. braunii was kept in Erlenmeyer flasks under constant agitation in a rotatory shaker (Infors $\mathrm{HT}^{\circledR}$ multitron), under fluorescent white light $\left(60 \mu \mathrm{mol}\right.$ of photons $\left.\mathrm{m}^{-2} \mathrm{~s}^{-1}\right)$ at $25 \pm 1^{\circ} \mathrm{C}$, until the biomass concentration 
achieved approximately $200 \mathrm{mg} / \mathrm{L}[19,22]$. Subsequently, biomass was cultured by discontinuous fed process in an airlift tubular photobioreactor, developed at the Fermentation Technology Laboratory of the Department of Biochemical-Pharmaceutical Technology, Faculty of Pharmaceutical Sciences, University of São Paulo. The photobioreactor system developed for the microalgae growth was constructed in a holder that contained five sets of cylindrical glass tubes. These tubes were illuminated by two $20 \mathrm{~W}$ fluorescent lamps. In addition, the system included a valve to collect samples, as well as a carbon dioxide control system and a nylon ball to prevent microalgae accumulating on the glass walls [19]. The $\mathrm{pH}$ was kept at $7.8 \pm 0.2$ using carbon dioxide. Phosphorus and nitrogen nutrients were daily replenished in required quantities previously determined as a function of the microalgae growth by a Spectrophotometer 600 plus (FEMTO ${ }^{\circledR}$ ) at $680 \mathrm{~nm}$ [19].

At the stationary phase, the biomass was removed from the photobioreactor by centrifugation (Sorvall ${ }^{\circledR}$ RC-5C Plus) for $20 \mathrm{~min}$, and the adsorbed salt was washed with distilled water. Finally, the biomass was dried in an oven (Fanem $\left.{ }^{\circledR} 320 \mathrm{E}\right)$ at $55{ }^{\circ} \mathrm{C}$ for $12 \mathrm{~h}$ and triturated with pestle and mortar. The particle size was standardized at $0.42 \mathrm{~mm}$ in Granutest ${ }^{\circledR}$ sieve and stored in a freezer. The obtained dry biomass had its content of total proteins and total lipids established as previously described [23].

\subsection{Preparation of Photoprotective Formulations}

Formulations were constituted of an emulsifying polymer ammonium acryloyldimethyltaurate/VP copolymer (Aristoflex ${ }^{\circledR}$ AVC) or a self-emulsifying base cetearyl alcohol (and) dicetyl hosphate (and) ceteth-10 phosphate (Crodafos ${ }^{\circledR}$ CES). The UV filters were the avobenzone (butyl methoxydibenzoylmethane) and octyl $p$-methoxycinnamate (ethylhexyl methoxycinnamate). The quantitative and qualitative compositions of the formulations are described in Table 1.

Table 1. Quantitative and qualitative composition $(\% w / w)$ of the formulations.

\begin{tabular}{|c|c|c|c|c|c|c|}
\hline \multirow{3}{*}{ Ingredients (Vendor/Supplier/Local) } & \multicolumn{6}{|c|}{ Concentration $(\% w / w)$} \\
\hline & \multicolumn{6}{|c|}{ Formulation Codes } \\
\hline & F2 & F3 & F4 & F6 & F7 & F8 \\
\hline Aristoflex ${ }^{\circledR}$ AVC (Pharmaspecial, Brazil) & 1.0 & 1.0 & 1.0 & 0.5 & 0.5 & 0.5 \\
\hline Crodafos ${ }^{\circledR}$ CES (Mapric, Brazil) & - & - & - & 6.0 & 6.0 & 6.0 \\
\hline Propylene glycol (Mapric, Brazil) & - & - & - & 5.0 & 5.0 & 5.0 \\
\hline Avobenzone (Fragon, Brazil) & 3.0 & - & 3.0 & 3.0 & - & 3.0 \\
\hline Octyl p-methoxycinnamate (Fragon, Brazil) & 10.0 & - & 10.0 & 10.0 & - & 10.0 \\
\hline B. braunii dry biomass & - & 10.0 & 10.0 & - & 10.0 & 10.0 \\
\hline Caprylic/Capric Triglyceride (Mapric, Brazil) & 3.5 & - & 3.5 & 3.5 & - & 3.5 \\
\hline $\begin{array}{l}\text { Phenoxyethanol (and) methylparaben (and) ethylparaben (and) butylparaben } \\
\text { (and) propylparaben (and) isobutylparaben (Mapric, Brazil) }\end{array}$ & \multicolumn{6}{|c|}{0.8} \\
\hline Purified water & \multicolumn{6}{|c|}{$*$} \\
\hline
\end{tabular}

* Sufficient to complete $100.0 \%$.

Emulsifying polymer formulations were prepared by the hydration of the Aristoflex ${ }^{\circledR}$ AVC in purified water with manual homogenization at room temperature. Propylene glycol and the preservative system were added and homogenized. Avobenzone and octyl $p$-methoxycinnamate were previously dissolved in caprylic/capric triglyceride and then incorporated into the gel. Finally, B. braunii dry biomass was added into the product, followed by manual homogenization. The Crodafos ${ }^{\circledR}$ CES self-emulsifying base formulations were prepared, as described: Phase A (aqueous) was composed by the mixture of ammonium acryloyldimethyltaurate/VP copolymer, purified water and propylene glycol homogenized mechanical stirring at $1000 \times g$; Phase B (oily) had the Crodafos ${ }^{\circledR}$ CES, caprylic/capric triglyceride, avobenzone and octyl $p$-methoxycinnamate. Both phases were individually heated 
at $75^{\circ} \mathrm{C}$ and then Phase B was incorporated into Phase A under mechanical stirring at $1000 \times g$. After Phase B incorporation, the stirring velocity was raised to 5000 $\mathrm{g}$ and maintained for $2 \mathrm{~min}$. The preservative system was added during the mechanical homogenization process. Formulations were cooled until reaching room temperature. Finally, as mentioned earlier, B. braunii dry biomass was added, followed by homogenization [23].

\subsection{In Vitro Photoprotective Activity and Photoestability}

The in vitro efficacy was evaluated by diffuse reflectance spectrophotometry with an integration sphere (Labsphere ${ }^{\circledR}$ UV2000S Ultraviolet Transmittance Analyzer) regarding the spectral range of 250 to $450 \mathrm{~nm}$. Samples were applied in polymethylmethacrylate (PMMA) plates with area of $1.3 \mathrm{mg} / \mathrm{cm}^{2}[4,24,25]$. Assays were performed in triplicates. The in vitro efficacy assessment was determined as estimated sun protection factor (SPF) and critical wavelength [24]. SPF and critical wavelength were calculated by the UV-2000 ${ }^{\circledR}$ program, using Equations (1) and (2), respectively [4,24,25].

$$
\mathrm{SPF}=\frac{\int_{290}^{400} E \lambda S \lambda d \lambda}{\int_{290}^{400} E \lambda S \lambda T \lambda d \lambda}
$$

where $E \lambda$ is the spectral erythematogenic efficacy of CIE (Commission Internationale de l'Eclairage); $S \lambda$ is the spectral solar radiation; $T \lambda$ is the spectral transmittance of the sample; and $d \lambda$ is the range of wavelengths.

$$
\int_{290}^{\lambda c} A \lambda . d \lambda=0.9 \int_{290}^{400} A \lambda . d \lambda
$$

where $A \lambda$ is the spectral absorbance of the sample and $d \lambda$ is the range of wavelengths.

PMMA plates containing the samples right after the efficacy test were subjected to artificial irradiation in a photoestability chamber (Atlas Suntest ${ }^{\circledR}$ CPS+) with fixed dose of $2088 \mathrm{~kJ} / \mathrm{m}^{2}$ (corresponding to the irradiation of one hour), irradiance equivalent to $55 \mathrm{~W} / \mathrm{m}^{2}$ and $35{ }^{\circ} \mathrm{C}$ [26]. Subsequently, samples had their SPF and critical wavelength values determined, as described earlier. These results were compared with those obtained before the irradiation step to estimate the influence of $B$. braunii microalgae on the functional photostability of the UV filters.

\subsection{Statistical Analysis}

The data were evaluated by the Minitab ${ }^{\circledR}$, version 17, using ANOVA (generalized linear model) or experimental design of the factorial type, including the significance level of $5 \%(p \leq 0.05)$ for the determination of significant results.

\section{Results and Discussion}

B. braunii was cultivated in photobioreactors $(\sim 4-5 \mathrm{~g} / \mathrm{L})$ and biomass comprised proteins (49.1\%) and lipids (25.65\%) with similar results to those reported in the literature [19]. The Aristoflex ${ }^{\circledR}$ AVC was used due to the fact that it is a synthetic gel-forming copolymer with adequate sensory properties and spreadability. The gel is non-irritating and gives adhesion with a pleasant sensation to the skin, without a sticky feeling, presenting transparency, in addition to stability in a wide $\mathrm{pH}$ value range. Furthermore, this polymer is stable against UV radiation and can act as a thickening agent and stabilizer for emulsions, since it is possible to use it with different oily phases, such as silicones, waxes and hydrocarbons, resulting in the formation of stable systems [27-30]. The Crodafos ${ }^{\circledR}$ CES was selected as as it is a phosphate self-emulsifying base that has high stability in oil/water systems. This base allows adequate film formation, theoretically contributing to SPF increase in the photoprotective samples [31,32]. 
The UVA and UVB filters addressed in this study have been used for three main reasons: (1) to obtain formulations with a broad-spectrum profile; (2) they are commercially available worldwide; and (3) their safety and efficacy has been established by several studies [33]. However, it is well known that avobenzone is a photolabile molecule that cleaves by irradiation and, when associated with octyl $p$-methoxycinnamate, has a higher probability of breakage and photo-induction interactions with the UVB filter, consequently causing a reduction in the UVA protection and the SPF of the sunscreen formulation $[11,26,34]$. Considering this, the association of avobenzone and octyl $p$-methoxycinnamate was used as a model of a photounstable system for the investigation of the putative photostabilizing action of B. braunii biomass.

Formulations containing only the biomass did not exhibit a significant SPF, demonstrating no photoprotective property by direct UV absorption. In contrast, since avobenzone is an UVA filter and octyl $p$-methoxycinnamate is an UVB one, the formulations containing these compounds showed a robust absorption of UV rays [4,35]. A photoprotector should promote action against UVA and UVB radiation, with a critical wavelength $(\lambda c)$ equal or greater than $370 \mathrm{~nm}-\mathrm{a}$ value that corresponds to $90 \%$ of the integrated area between 290 to $400 \mathrm{~nm}$ (spectral range that covers UVB and UVA radiation) $[24,25,36]$.

When comparing the formulations prepared with the emulsifying polymer Aristoflex ${ }^{\circledR}$ AVC containing only the UV filters (F2) and associated to the microalgae (F4), we observed that F2 and F4 maintained the critical wavelength values above $370 \mathrm{~nm}$, after the irradiation process. Both formulations provided measurable SPF values (Table 2 and Figure 1). However, the performance of F4 regarding this parameter was inferior to F2, since the values determined before and after irradiation were lower.

Table 2. Sun protection factor (SPF) values obtained from the F2 and F4 formulations.

\begin{tabular}{ccc}
\hline Formulations & Irradiation & SPF \\
\hline \multirow{2}{*}{ F2 } & BR & $10.0 \pm 2.1$ \\
\cline { 2 - 3 } & IR & $8.0 \pm 4.5$ \\
\hline \multirow{2}{*}{ F4 } & BR & $7.0 \pm 1.0$ \\
\cline { 2 - 3 } & IR & $5.6 \pm 1.2$ \\
\hline
\end{tabular}

BR-before radiating; IR-irradiated.
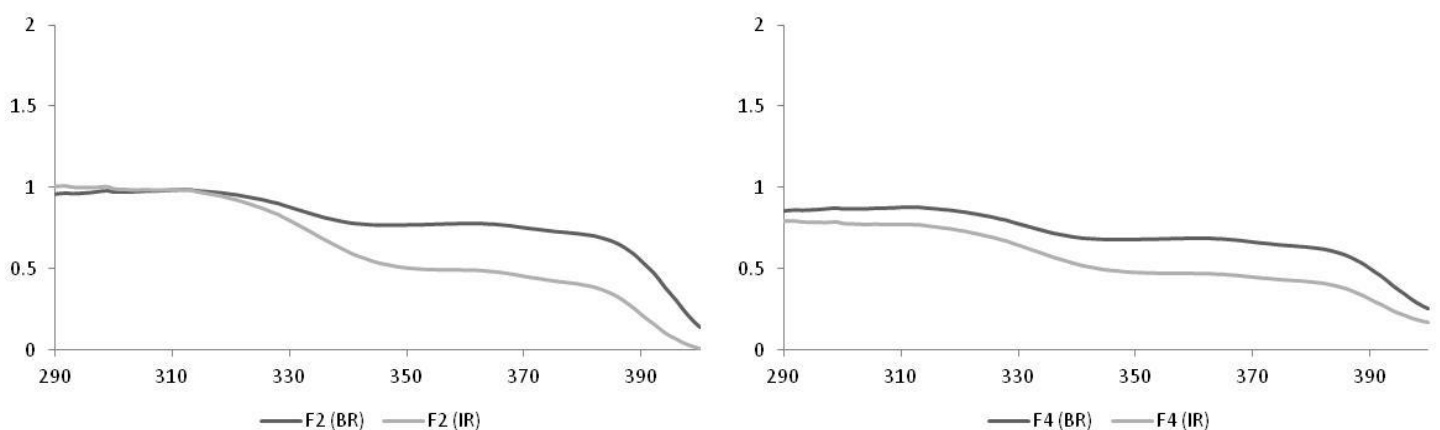

Figure 1. Spectra obtained from the F2 and F4 formulations. BR-Before Radiating; IR-Irradiated.

When the vehicle was changed from emulsifying polymer to Crodafos ${ }^{\circledR}$ CES self-emulsifying base, it was found that F6 and F8 (before and after the irradiation process) maintained the critical wavelength $(\lambda c)$ in the recommended value $(370 \mathrm{~nm})$ for promoting action in the broad spectrum $[24,25,36]$. Regarding the SPF of the formulations, the F6 - containing only filters-presented a much higher value than F8, composed of filters and B. braunii microalgae dry biomass (Table 3 and Figure 2). 
Table 3. SPF values obtained from the F6 and F8 formulations.

\begin{tabular}{ccc}
\hline Formulations & Irradiation & SPF \\
\hline \multirow{2}{*}{ F6 } & BR & $29.0 \pm 4.7$ \\
\cline { 2 - 3 } & IR & $8.0 \pm 1.1$ \\
\hline \multirow{2}{*}{ F8 } & BR & $12.0 \pm 1.5$ \\
\cline { 2 - 3 } & IR & $5.0 \pm 1.0$ \\
\hline
\end{tabular}
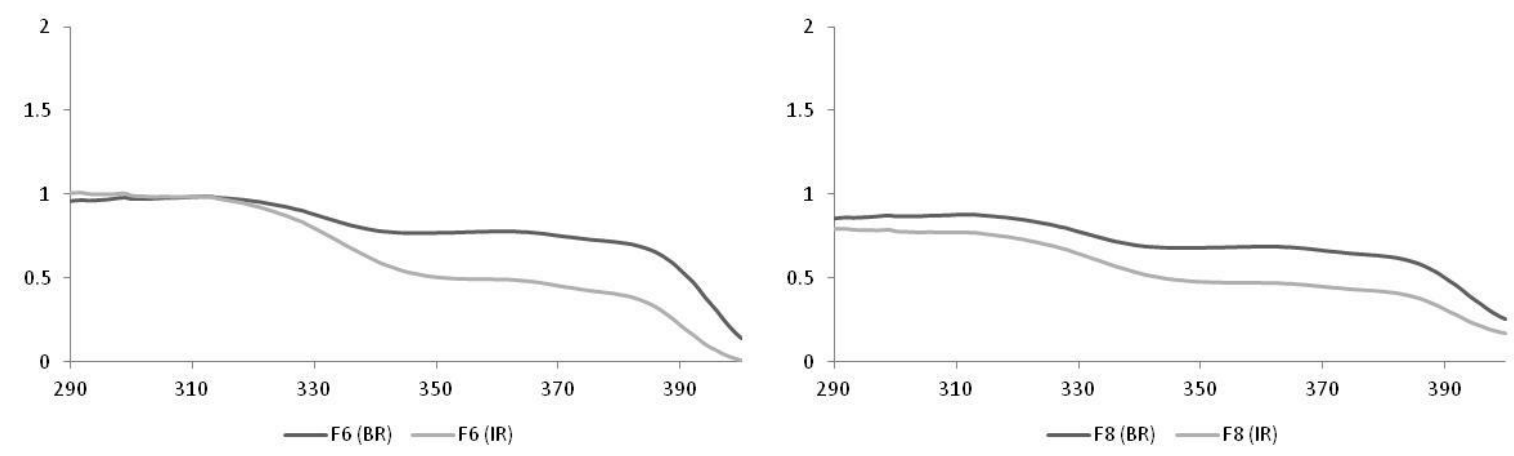

Figure 2. Spectra obtained from the F6 and F8 formulations.

Figure 3 shows that all variables influenced the effect of the SPF of F6 to F8, and the filters contributed the most to this effect (Figure 4). It was verified that the irradiation and the microalgae incorporation promoted SPF reduction in the formulation and only the UV filters were responsible for the photoprotective action [37].

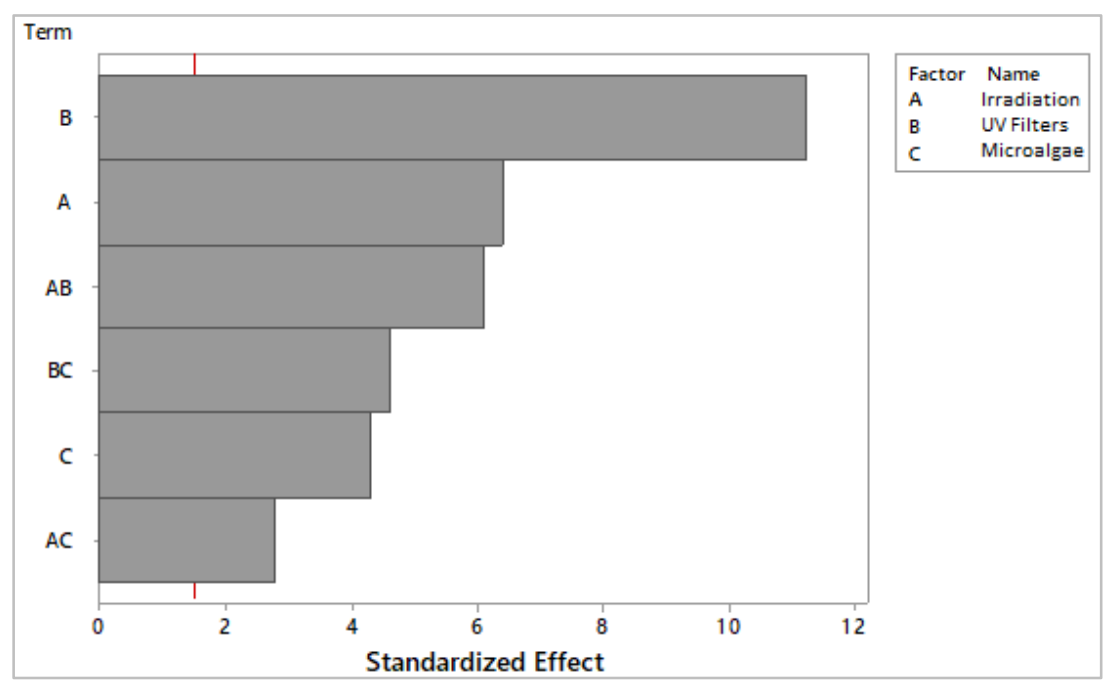

Figure 3. Pareto plot illustrating the effect of each variable and combinations over the SPF (sun protection factor) from formulations F6 to F8. The vertical red line defined the confidence interval.

Comparing the SPF performance of the photoprotective formulations in the different vehicles, it was observed that Crodafos ${ }^{\circledR}$ CES self-emulsifying base promoted better SPF when it was associated with the microalgae before the irradiation process. There was no difference in the SPF value after the same process in comparison with the value for the Aristoflex ${ }^{\circledR}$ AVC emulsifying polymer. In addition, it was possible to observe that in both vehicles, the formulation containing only the UV filters resulted in higher efficacy than those containing the microalgae association. Regardless of the cosmetic base, the incorporation of $B$. braunii dry biomass in the photoprotective formulation diminished the anti-UVB 
efficacy, probably due to the interaction of the UV filters with the compounds from microalgae biomass, for example, the presence of proteins in about 49\% [23]. Some studies have pointed out that certain UV filters can react with free amino acids and proteins since they have the structure of the electrophilic carbonyl group, which reacts with the nucleophilic group of the proteins under thermal conditions and/or through irradiation, culminating in the formation of products that influence the action spectrum of the UV filter [38-41]. The Crodafos ${ }^{\circledR}$ CES self-emulsifying base provided the best SPF and maintained the critical wavelength $(\mathrm{nm})$ in the recommended value $(370 \mathrm{~nm})$, possibly due to a better formation of uniform, thick and non-transparent films that would provide high photoprotection levels [36,40].

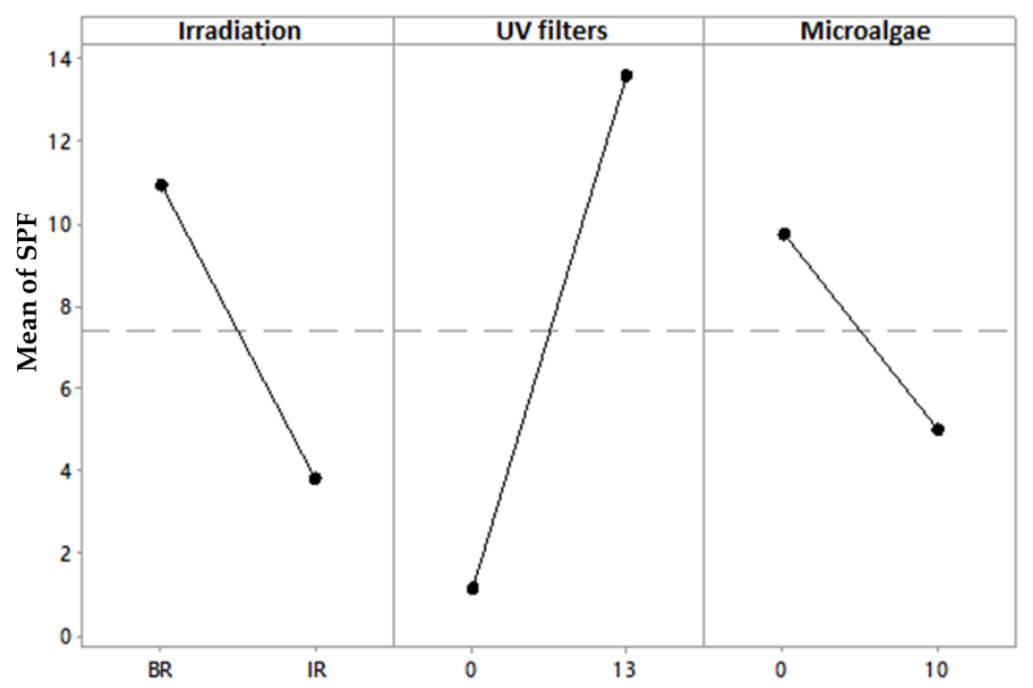

Figure 4. Main effects plot for SPF of formulations F6 to F8. Line with small dots represented the overall mean.

\section{Conclusions}

Under the experimental conditions adopted, B. braunii dry biomass did not promote in vitro an adequate sun protection effect when associated with avobenzone and octyl $p$-methoxycinnamate. It was verified that, when incorporating the microalgae along with the UV filters, the resulted SPF values were due to the presence of UV filters and not the B. braunii dry biomass. Also, it was observed that the Crodafos ${ }^{\circledR}$ CES self-emulsifying base promoted better SPF in comparison with the emulsifying polymer. Besides the stated, our results allow us to highlight that sunscreen development containing natural substances must be investigated in a case-by-case process, since negative interactions may occur in this complex formulation.

Author Contributions: Conceptualization, A.R.B., M.B.A., J.C.M.d.C.; methodology, M.B.A., T.M.C., F.R.L., E.T.M.K., A.L.M.-J.; formal analysis, A.R.B., M.B.A., J.C.M.d.C., A.L.M.-J., M.V.R.V., C.R., F.R.L., E.T.M.K.; investigation, A.R.B., M.B.A., J.C.M.d.C., A.L.M.-J., M.V.R.V., C.R.; writing-original draft preparation, M.B.A., A.L.M.-J., T.M.C., E.T.M.K.; writing-review and editing, A.R.B., M.B.A., J.C.M.d.C., A.L.M.-J., M.V.R.V., C.R., F.V.L., E.T.M.K., F.R.L.; supervision, A.R.B., J.C.M.d.C.; project administration, A.R.B., M.B.A., J.C.M.d.C.; funding acquisition, A.R.B., J.C.M.d.C., M.V.R.V. All authors have read and agreed to the published version of the manuscript.

Funding: Authors greatly acknowledge the Conselho Nacional de Desenvolvimento Científico e Tecnológico (CNPq) Process 305250/2019-1; Coordenação de Aperfeiçoamento de Pessoal de Nível Superior-Brasil (CAPES) Finance Code 001; and São Paulo Research Foundation (FAPESP) Process 2015/11194-6.

Conflicts of Interest: The authors declare no conflict of interest. 


\section{References}

1. Peres, D.A.; de Oliveira, C.A.; da Costa, M.S.; Tokunaga, V.K.; Mota, J.P.; Rosado, C.; Consiglieri, V.O.; Kaneko, T.M.; Velasco, M.V.R.; Baby, A.R. Rutin increases critical wavelength of systems containing a single UV filter and with good skin compatibility. Ski. Res. Technol. 2016, 22, 325-333. [CrossRef] [PubMed]

2. Martinez, R.M.; Pinho-Ribeiro, F.A.; Steffen, V.S.; Caviglione, C.V.; Vignoli, J.A.; Barbosa, D.S.; Baracat, M.M.; Georgetti, S.R.; Verri, W.A.; Casagrande, R. Naringenin inhibits UVB irradiation-induced inflammation and oxidative stress in the skin of hairless mice. J. Nat. Prod. 2015, 78, 1647-1655. [CrossRef] [PubMed]

3. Kim, M.C.; Hwang, E.; Kim, T.; Ham, J.; Kim, S.Y.; Kwon, H.C. Nocatriones A and B, photoprotective tetracenediones from a marine-derived Nocardiopsis sp. J. Nat. Prod. 2014, 77, 2326-2330. [CrossRef]

4. De Oliveira, C.A.; Peres, D.D.; Rugno, C.M.; Kojima, M.; De Oliveira Pinto, C.A.S.; Consiglieri, V.O.; Kaneko, T.M.; Rosado, C.; Mota, J.; Velasco, M.V.R.; et al. Functional photostability and cutaneous compatibility of bioactive UVA sun care products. J. Photochem. Photobiol. B Biol. 2015, 148, 154-159. [CrossRef] [PubMed]

5. Hupel, M.; Poupart, N.; Gall, E.A. Development of a new in vitro method to evaluate the photoprotective sunscreen activity of plant extracts against high UV-B radiation. Talanta 2011, 86, 362-371. [CrossRef] [PubMed]

6. Suh, S.; Hwang, J.; Park, M.; Seo, H.H.; Kim, H.; Lee, J.H.; Moh, S.H.; Lee, T. Anti-inflammation activities of Mycosporine-like amino acids (MAAs) in response to UV radiation suggest potential anti-skin aging activity. Mar. Drugs 2014, 5174-5187. [CrossRef] [PubMed]

7. Martins, F.J.; Caneschi, C.A.; Vieira, J.L.F.; Barbosa, W.; Raposo, N.R.B. Antioxidant activity and potential photoprotective from amazon native flora extracts. J. Photochem. Photobiol. B Biol. 2016, 161, 34-39. [CrossRef]

8. Saewan, N.; Jimtaisong, A. Natural products as photoprotection. J. Cosmet. Dermatol. 2015, 14, 47-63. [CrossRef]

9. Lotan, A. Biologic Sunscreen Composition. WO2012093388A2, 12 July 2012.

10. Kawakami, C.M.; Gaspar, L.R. Mangiferin and naringenin affect the photostability and phototoxicity of sunscreens containing avobenzone. J. Photochem. Photobiol. B Biol. 2015, 151, 239-247. [CrossRef]

11. Afonso, S.; Horita, K.; Sousa, E.; Silva, J.P.; Almeida, I.F.; Amaral, M.H.; Lobão, P.A.; Costa, P.C.; Miranda, M.S.; Esteves Da Silva, J.C.G.; et al. Photodegradation of avobenzone: Stabilization effect of antioxidants. J. Photochem. Photobiol. B Biol. 2014, 140, 36-40. [CrossRef]

12. Elliott, A.; Mundy, C.J.; Gosselin, M.; Poulin, M.; Campbell, K.; Wang, F. Spring production of mycosporine-like amino acids and other UV-absorbing compounds in sea ice-associated algae communities in the Canadian Arctic. Mar. Ecol. Prog. Ser. 2015, 541, 91-104. [CrossRef]

13. Buono, S.; Langellotti, A.L.; Martello, A.; Bimonte, M.; Tito, A.; Carola, A.; Apone, F.; Colucci, G.; Fogliano, V. Biological activities of dermatological interest by the water extract of the microalga Botryococcus braunii. Arch. Dermatol. Res. 2012, 304, 755-764. [CrossRef]

14. Wang, H.M.D.; Chen, C.C.; Huynh, P.; Chang, J.S. Exploring the potential of using algae in cosmetics. Bioresour. Technol. 2015, 184, 355-362. [CrossRef] [PubMed]

15. Maadane, A.; Merghoub, N.; Ainane, T.; El Arroussi, H.; Benhima, R.; Amzazi, S.; Bakri, Y.; Wahby, I. Antioxidant activity of some Moroccan marine microalgae: Pufa profiles, carotenoids and phenolic content. J. Biotechnol. 2015, 215, 13-19. [CrossRef]

16. Batista, A.P.; Gouveia, L.; Bandarra, N.M.; Franco, J.M.; Raymundo, A. Comparison of microalgal biomass profiles as novel functional ingredient for food products. Algal Res. 2013, 2, 164-173. [CrossRef]

17. Hagino, H.; Saito, M. Use of Algal Proteins in Cosmetics. EP03029218A, 22 September 2010.

18. Furuhashi, K.; Noguchi, T.; Okada, S.; Hasegawa, F.; Kaizu, Y.; Imou, K. The surface structure of Botryococcus braunii colony prevents the entry of extraction solvents into the colony interior. Algal Res. 2016, 16, 160-166. [CrossRef]

19. Pérez-Mora, L.S.; Matsudo, M.C.; Cezare-Gomes, E.A.; Carvalho, J.C. An investigation into producing Botryococcus braunii in a tubular photobioreactor. J. Chem. Technol. Biotechnol. 2016, 91, 3053-3060. [CrossRef]

20. Furuhashi, K.; Hasegawa, F.; Saga, K.; Kudou, S.; Okada, S.; Kaizu, Y.; Imou, K. Effects of culture medium salinity on the hydrocarbon extractability, growth and morphology of Botryococcus braunii. Biomass Bioenergy 2016, 91, 83-90. [CrossRef]

21. UTEX Culture Collection of Algae UTEX. Available online: https://utex.org/products/chus-medium?variant= 30991781953626 (accessed on 16 April 2018).

22. Eroglu, E.; Okada, S.; Melis, A. Hydrocarbon productivities in different Botryococcus strains: Comparative methods in product quantification. J. Appl. Phycol. 2011, 23, 763-775. [CrossRef] 
23. Ariede, M.B. Aplicação do extrato da microalga Botryococcus braunii em formulações cosméticas fotoprotetoras. Master's Thesis, University of São Paulo, São Paulo, Brazil, 2016.

24. Europe Cosmetics. In Vitro Method for the Determination of the UVA Protection Factor and "Critical Wavelength" Values of Sunscreen Products; COLIPA: Auderghem, Belgium, 2011.

25. United States Food and Drug Administration, Department of Health and Human Services. 21 CFR Parts 201 and 310. Labeling and effectiveness testing; sunscreen drug products for over-the-counter human use. Fed. Regist. 2011, 76, 35620-35665.

26. Scalia, S.; Mezzena, M. Photostabilization effect of quercetin on the UV filter combination, butyl methoxydibenzoylmethane-octyl methoxycinnamate. Photochem. Photobiol. 2010, 86, 273-278. [CrossRef] [PubMed]

27. Peres, L.P.A.; Dias, I.L.T. Desenvolvimento e avaliação de formulações em gel para veiculação de ácido salicílico. Rev. Multidiscip. Saúde 2011, 3, 26-36.

28. Adriano, J.; Netz, D.J.A.; Bresolin, T.M.B.; Freitas, R.A.; Couto, A.G. Development of a topical gel containing dried extract of Ipomoea pes-caprae brasiliensis (L.) R. Br. (Convolvulaceae). J. Med. Plants Res. 2014, 8, 1074-1080. [CrossRef]

29. Zanini, M. Gel de ácido tricloroacético-Uma nova técnica para um antigo ácido. Med. Cutan. Ibero. Lat. Am. 2007, 35, 14-17.

30. Daniels, R. Emulsifier-Free, Polymer-Stabilized Foam Formulations. EP2509565A1, 17 October 2012.

31. Pinto, C.A.S.D.O. Influência da rutina na fotoestabilização da avobenzona (filtro UVA) e do p-Metoxicinamato de octila (Filtro UVB). Ph.D. Thesis, University of São Paulo, São Paulo, Brazil, 2014.

32. Sohn, M.; Herzog, B.; Osterwalder, U.; Imanidis, G. Calculation of the sun protection factor of sunscreens with different vehicles using measured film thickness distribution-Comparison with the SPF in vitro. J. Photochem. Photobiol. B 2016, 159, 74-81. [CrossRef] [PubMed]

33. Balogh, T.S.; Velasco, M.V.R.; Pedriali, C.A.; Kaneko, T.M.; Baby, A.R. Ultraviolet radiation protection: Current available resources in photoprotection. An. Bras. Dermatol. 2011, 86, 732-742. [CrossRef] [PubMed]

34. Kim, E.J.; Kim, M.J.; Im, N.R.; Park, S.N. Photolysis of the organic UV filter, avobenzone, combined with octyl methoxycinnamate by nano-TiO 2 composites. J. Photochem. Photobiol. B Biol. 2015, 149, 196-203. [CrossRef]

35. Kumar, V.; Jahan, F.; Kameswaran, K.; Mahajan, R.V.; Saxena, R.K. Eco-friendly methodology for efficient synthesis and scale-up of 2-ethylhexyl-p-methoxycinnamate using Rhizopus oryzae lipase and its biological evaluation. J. Ind. Microbiol. Biotechnol. 2014, 41, 907-912. [CrossRef]

36. ANVISA. Resolução-RDC $N^{\circ} 30$, de $1^{\circ}$ de junho de 2012; Agência Nacional de Vigilância Sanitária (ANVISA): Brasília, Brazil, 2012; Volume 2012, pp. 760-763.

37. Peres, D.D.; Ariede, M.B.; Candido, T.M.; Almeida, T.S.; Lourenço, F.R.; Consiglieri, V.O.; Kaneko, T.M.; Velasco, M.V.R.; Baby, A.R. Quality by design (QbD), process analytical technology (PAT), and design of experiment applied to the development of multifunctional sunscreens. Drug Dev. Ind. Pharm. 2017, 2, 246-256. [CrossRef]

38. Peres, D.A.; Hubner, A.; De Oliveira, C.A.; De Almeida, T.S.; Kaneko, T.M.; Consiglieri, V.O.; Pinto, C.A.S.D.O.; Velasco, M.V.R.; Baby, A.R. Hydrolyzed collagen interferes with in vitro photoprotective effectiveness of sunscreens. Braz. J. Pharm. Sci. 2017, 53, 16119. [CrossRef]

39. Stiefel, C.; Schwack, W.; Nguyen, Y.T.H. Photostability of cosmetic UV filters on mammalian skin under UV exposure. Photochem. Photobiol. 2015, 91, 84-91. [CrossRef] [PubMed]

40. Sambandan, D.R.; Ratner, D. Sunscreens: An overview and update. J. Am. Acad. Dermatol. 2011, 64, 748-758. [CrossRef] [PubMed]

41. Stiefel, C.; Schwack, W. Reactivity of cosmetic UV filters towards skin proteins: Model studies with Boc-lysine, Boc-Gly-Phe-Gly-Lys-OH, BSA and gelatin. Int. J. Cosmet. Sci. 2014, 36, 561-570. [CrossRef] [PubMed]

(C) 2020 by the authors. Licensee MDPI, Basel, Switzerland. This article is an open access article distributed under the terms and conditions of the Creative Commons Attribution (CC BY) license (http://creativecommons.org/licenses/by/4.0/). 